\title{
Customer Based Retail Brand Equity Dimensions on Retail Brand Equity of Pakistani Markets
}

\author{
Muhammad Umair, Mubarak Ahmad \\ Department of Business Administration and Commerce, University of Sargodha, Sargodha, Pakistan \\ Email address: \\ mumair342@yahoo.com (M. Umair), mubarakahmad322@gmail.com (M. Ahmad) \\ To cite this article: \\ Muhammad Umair, Mubarak Ahmad. Customer Based Retail Brand Equity Dimensions on Retail Brand Equity of Pakistani Markets. \\ Journal of Investment and Management. Vol. 7, No. 3, 2018, pp. 102-107. doi: 10.11648/j.jim.20180703.15
}

Received: June 26, 2018; Accepted: July24, 2018; Published: August 15, 2018

\begin{abstract}
Customer brand equity become the major concept in last decades due to increase the competition and also rise in demands of the customer. This study investigate the impact of customer brand equity in Pakistan in embryonic areas and mature areas because in immature area customer preference change and in mature areas customer demands may also be differ so for checking the retailer base customer's brand equity [RBCBE]. We select the two markets of Pakistan Hakim hyper Market [HHM] and Metro cash and carry [MCC]. Sample was selected 100 respondents in both Regression analyses; Pearson's correlation and Cronbach alpha used for the purpose of the investigation and results reveal that market loyalty have positive impact on retail brand equity in backward areas while market association have strong positive impact on retail brand equity in advance areas.
\end{abstract}

Keywords: Customer Based Brand Equity [CBBE], Hakim Hyper Market [HHM], Metro Cash and Carry [MCC], Pakistan's Retailing Business, Cronbach Alpha, Regression Analysis Pearson's Correlation

\section{Introduction}

In recent pattern, people prefer brands rather than products, it was an old concept when people brought inferior products. Now with the passage time and improving pattern mostly people have more conscious of brands because some mental associations are attached with brand. This mental attribute lead the development of brand.

Brand equity refers the commercial value which is derived from consumer preference of the brand name of specific product or service.

The concept of brand equity have been fundamental source of corporation it starts in 1980 and due to the increase in competition this concept become the most popular among the all organization, in these days if company want to expend itself then management must focus to the attribution of products and make the appropriate decision of packing and presenting for creating the brand equity.

Brand equity is a long term process, if corporations want to improve the brand then have to make decisions for long term rather than short term.

\subsection{Concept of Brand in Pakistan}

Same concept has existed in developing countries like Pakistan.

There are some aspects which contribute in Pakistan market which are:

a) Large market size due to the 140 million population

b) Per capita income according to purchasing capacity is $\$ 2000$.

So in Pakistan everyone wants to luxuries rather than simple products and visited in braded places like metro retailer store and in backwards area also is leading towards the middle class or some time business class.

In this research we study the two market places where mostly customer visit for choosing the appropriate brands one market situated in backward area and other market situated in advance area.

\subsection{Retailing Sector of Pakistan}

According to the Punjab Board of investment retailing sector is the third major sector in Pakistan after agriculture and industry sector. Retail sector in Pakistan is sharply grow by recent years. Many experts have visit and gain benefit in 
emerging markets and makes new setup in Pakistan which is one best example is Metro Cash and Carry Lahore.

\subsection{Hakim Hyper Market}

Hakim Hyper Market [HHM] is one and only leading hyper market in Mandi Bahauddin. Thousands of customer from city and surrounding daily visit it. Their slogan is all necessities of life available under single roof. Mostly Elite class people used to visit it and some middle class modern citizen also gives priority HHM. It was incorporated since 2014 and attraction in its potential customer and sales consistently rising every year. [Zee Shan Marketing manager of HHM].

\subsection{Metro Retail Market}

Metro [cash \& carry] first time open wholesale center in 2007 in Pakistan, by sharping expending its activities 5 more centers where established by the metro in short span time [18 months]. Metro- Habib and metro combine their business and operate the activities in whole country. Now Metro cash \& carry is a subject of international metro group and operate its activities in whole world and Habib metro cash \& carry operate business in Pakistan as a sub-ordinate of metro group.

If we see the retailing point of view then it can be say that, Habib metro [cash \& carry] operate its business $90 \%$ at local level.

In this study we see that which customer base retail brand equity dimensions are applying at backward areas and advance areas.

\section{Purpose of the Study}

The basic purpose of this study is to investigating the customer based retail brand equity dimensions on retailer brand equity amongst Hakim Hyper Market customers [backward area] and Metro Retailer Market [Advance area].

\section{Literature Review}

According to Musekiwa, Chiguvi, \& Hogo [2013] the concept of brand equity has been vested all surrounding to the global area. They check the impact on brand equity by OK store and find that awareness of the customer concerned to the brand have significant impact on the brand equity moreover loyalty has also play an significant role on brand equity.

For choosing the brand customer psychological attributes are also be the associated while choosing the brand so for seen the customer psychological attributes Dolatabadi, Kazemi, \& Soltani [2012] award the result that brand personality create the link between brand equity and product sale because customer have chosen according to own psychological attributes and this attributes create the link between brand equity and brand sale. Another research conduct by Sloot, Verhoef, \& Franses [2005] to see the hedonic level of products those which are out of the reaction stock on consumer they investigation shows that high equity brands create significant role in loyalty as compare to low equity brands in case of hedonic levels consumer will switch to other brands.

Baldauf, Cravens, Diamantopoulos, \& Zeugner-Roth [2009] Conduct the research by investigation on product country image and market efforts on brand equity, findings show that both variables contribute the positive impact on brand equity.

Bendixen, Bukasa, \& Abratt [2004] investigate by applying conjoint analysis experiment and conclude that price and delivery play vital role in the field of brand equity, according to them premium can make in case of high brand equity by the company. van Riel, Mortanges, \& Streukens, [2005] say that brand equity is necessary for industrial branding it also stated that product brand equity mostly interfere in physically product attributes and its distribution process and service attributes create the link with corporate brand equity.

Zaichkowsky, Parlee, \& Hill [2010] investigate the brand equity and perceiving market place and conclude that customer has not much aware about the real facts of the company authors recommended that company should improve by giving all necessary information on the front of the company website. Kim \& Kim [2005] Shows the positive relation between brand equity and sampled firms due to the customer base brand equity, brand awareness, its loyalty perceived quality and its image. Kim Y., The Impact of Brand Equity and the Company's Reputation on Revenues [2008] Find the positive relation between brand equity and company reputation by applying integrated market communication model and also shows that these two variables interference the revenue of the firm. DelVecchio, Jarvis, Klink, \& Dineen [2007] Indication that jobs seekers prefer strong brands rather than weak brands. They investigate that high brand equity may create more job opportunities.

It is prove that Brands are the most important asset for the firms. Brand dimensions [brand awareness, brand trust perceive quality and brand loyalty] have significant link with Brand equity Dib \& Alhaddad [2014]. Khan, Rahmani, Hoe, \& Chen [2015] Apply equity dimensions on fashion industry and conclude that perceive quality have more impact on loyalty and purchasing even less impact as compare to the brand image. Jara \& Cliquet [2012] Investigate by applying qualitative methodology and confirmative analysis and also apply the structural equation modeling that brand awareness and perceive quality have strong impact on customer base brand equity. KARADENIZ [2010] says about the importance of brand equity that global competition has create the strong concept of brand equity moreover says that customer focus strategy can be helpful for arising the brand equity.

Yew Leh \& Lee [2011] Suggest that marketers must focus on the broad activities moreover, according to their point of view that awareness is necessary about the brand. Roy [2016] Conduct the research in Kolkata and findings show that strong impact of brand equity on customer delights.

Above literature proof that strong connection of Customer 
Based Retail Brand Equity Dimensions on

Retail brand Equity. So, in this study we are going to check this connection in Pakistan by applying the samples on Hakim Hyper Market Mandi Bahuddin and Metro cash and carry Lahore.

\section{Framework and Hypothesis}

Gunawardane [2015] stated that awareness and perceive quality have more impact on customer decision and less impact of other variables so at the end conclude that brand equity have strong impact on customer.

Other findings by Yaseen, Tahira, Anwar, \& Gulzar [2011] that there is insignificant link of loyalty and awareness and significant contribution of perceive quality on profitability.

Brand awareness is important variable in case of consumer response, further prove by that brand awareness have more impact on consumer response.

AKHTAR, AHMED, JAFAR, RIZWAN, \& NAWAZ [2016] Investigate in case of Reseller Perspective in Mobile Sector of Pakistan that brand awareness has strong relation with brand loyalty and brand loyalty have impact on brand equity thus we can say that

H1: Market awareness positive impact on Retail Brand Equity [RBE] of Hakim Hyper Market

H2: Market awareness positive impact on Retail Brand Equity [RBE] of Metro Retail Market

del RõÂo, VaÂzquez, \& Iglesias [2001] Say that brand association has directly impact on consumer behavior.

Moreover, wang [2015] say that brand association analysis is necessary requirement in brand equity thus:

H3: Brand association has positive impact on Retail Brand [RBE] Equity Hakim Hyper Market.

H4: Brand association has positive impact on Retail Brand Equity [RBE] of Metro Retail Market.

Awan \& Rehman [2014] Prove the link between customer satisfaction and brand loyalty.

According to this study we can say that if customer satisfied then will attract toward the brand.
Customer loyalty has great impact on brand equity by Martisiute, Vilutyte, \& Grundey [ 2010] prove that cognitive loyalty has strong impact on customer decisions.

Another study captivated by checking the link between customer behavior and loyalty by Brasini \& Tassinari [ 2003] that higher brand locality has impact on the psychological attributes of customer.

Thus we can say that:

H5: Brand Loyalty has positive impact on Retail Brand Equity [RBE] Hakim Hyper Market

H6: Brand Loyalty has positive impact on Retail Brand Equity [RBE] of Metro Cash and carry.

Product perceive quality play significant role in behavior of customer. According to Saleem, Ghafar, Ibrahim, Yousuf, $\&$ Ahmed [2015] perceive quality and customer satisfaction create the significant link with customer decision. Moreover customer has more expect then actual receive.

Yee, San, \& Khoon [2011] Prove that customer is more conscious of quality of product at the time of purchasing decision in case of automobile.

So above studies for significant role of perceive quality we can check its impact on hyper markets in Pakistan so we build following statement.

H7: Perceive quality has positive impact on Retail Equity Hakim Hyper Market.

H8: Perceive quality has positive impact on Retail Equity of Metro Retail Market.

Measurement

Primary data has collect for study by using 5 Likert scale which 1 represent strongly agree, 2 represent agree, 3 present neutral, 4 present disagree and at 5 point present strongly disagree. These questioners were including brand equity and its dimensions which are awareness, associations, perceive quality and loyalty Questioners were conducted for 100 respondents which just $80 \%$ receive remaining were spoiling while collecting.

\section{Results}

Table 1. Reliability results of Metro hyper market.

\begin{tabular}{llllll}
\hline RBE Dimensions & Brand Awareness & Brand Association & perceive Quality & Brand Loyalty & Retail brand Equity \\
\hline Cronbach's alpha & 0.532 & 0.49 & 0.795 & 0.714 & 0.527 \\
\hline
\end{tabular}

Above data show the reliability data of brand equity and its dimensions in metro hyper market where by perceive quality, and brand loyalty have more reliable than brand awareness, brand association and brand equity.

Table 2. Hakim Hyper Market.

\begin{tabular}{llllll}
\hline RBE Dimensions & Brand Awareness & Brand Association & perceive Quality & Brand Loyalty & Retail brand Equity \\
\hline Cronbach's alpha & 0.790 & 0.557 & 0.613 & 0.816 & 0.521 \\
\hline
\end{tabular}

Above data shows the strong reliability of brand association, perceive quality and brand loyality. Other variables show less reliability as compare to these mention variables.

Pearson correlation

Table 3. Metro Hyper Market.

\begin{tabular}{llll}
\hline & Brand Awareness & Brand Association & perceive Quality \\
\hline Retail Brand Equity & 0.74 & 0.16 & 0.36 \\
\hline
\end{tabular}


Above table show the validity results of retail brand equity and its dimensions of metro hyper market which show that brand awareness value have 0.74 , Brand association have 0.16 , perceive quality have 0.36 , brand loyalty have 0.07 . so according to findings it is prove that there is positive correlation of all variables and strong correlations are Brand awarness.

Table 4. Hakim Hyper Market.

\begin{tabular}{lllll}
\hline & Brand Awareness & Brand Association & perceive Quality & Brand Loyalty \\
\hline Retail Brand Equity & 0.53 & 0.41 & 0.57 & 0.77 \\
\hline
\end{tabular}

Above table show the validity results of retail brand equity and its dimensions of Hakim hyper market which show that brand awareness value have 0.53 , Brand association have 0.41 , perceive quality have 0.57 , brand loyalty have 0.77 . according to above results there is positive correlation of brand awareness, brand association perceive quality and brand loyalty. But, according to finding brand loyalty has more important factor in immature areas.

Table 5. Correlation of RBE of Metro Hyper Market.

\begin{tabular}{lllll}
\hline RBE Dimensions & Brand Awareness & Brand Association & perceive Quality \\
\hline Brand awareness & 1 & 0.34 & 0.48 & Brand Loyalty \\
Brand Association & 0.34 & 1 & 0.42 & 0.38 \\
Perceive quality & 0.48 & 0.42 & 1 & 0.43 \\
Loyalty & 0.38 & 0.43 & 0.27 & 0.27 \\
\hline
\end{tabular}

Above table shows the different correlation results. Whereby brand association, perceive quality and brand loyalty have positive correlation with brand awareness. Other variables value are brand awareness 0.34 , perceive quality
0.42 and brand loyality are 0.43 with brand association.

Similarly perceive quality has more correlated with brand awareness, brand association and brand loyalty and Loyalty has also show positive correlation with other variables.

Table 6. Correlation of RBE of Hakim Hyper Market.

\begin{tabular}{lllll}
\hline RBE Dimensions & Brand Awareness & Brand Association & perceive Quality & Brand Loyalty \\
\hline Brand awareness & 1 & 0.57 & 0.54 & 0.51 \\
Brand association & 0.57 & 1 & 0.39 & 0.41 \\
Perceive quality & 0.72 & 0.57 & 1 & 0.57 \\
Loyalty & 0.51 & 0.41 & 0.57 & 1 \\
\hline
\end{tabular}

Immature area Brand association, perceive quality and brand loyalty have more strong relationship with brand awareness as compare to the other variables like brand association, perceive quality and loyalty.

Table 7. Regression analyses of RBE Dimensions of Hakim Hyper Market.

\begin{tabular}{lllll}
\hline Coefficients Unstandardized coefficients & \multicolumn{2}{l}{ Standardized coefficients } & & \\
\hline Model & B & Standard Error & Beta & t \\
\hline Constant & 0.554 & 0.257 & 0.704 & 2.152 \\
Loyalty & 0.652 & 0.127 & 0.38 & 0.134 \\
Association & 0.012 & 0.112 & 0.014 & -0.000 \\
Perceive quality & -0.01 & 0.091 & -0.001 & 0.913 \\
Awareness & 0.119 & 0.126 & 0.130 & 0.994 \\
\hline
\end{tabular}

\section{Dependent variable: Mean of RBE}

Above multiple linear regressions show the contribution of each dimension in hakim hyper market. According to the above results the beta of loyalty has 0.704 which show that loyalty $70 \%$ influence in hakim hyper market. While association influence is just $1.4 \%$ and awareness have $13 \%$. furthermore loyalty has significant positive impact on hakim hyper market so one hypothesis accept and others are rejected.

Table 8. Regression analyses of RBE Dimensions of Metro Hyper Market.

\begin{tabular}{|c|c|c|c|c|c|}
\hline \multirow{2}{*}{$\begin{array}{l}\text { Coefficients }{ }^{\text {a }} \text { Unstandardized coefficients } \\
\text { Model }\end{array}$} & \multicolumn{5}{|c|}{ standardized coefficients } \\
\hline & B & Standard error & Beta & $\mathbf{t}$ & Sig. \\
\hline Constant & -0.155 & 0.808 & & -0.192 & 0.849 \\
\hline Mean of association & -0.77 & 0.302 & -0.032 & -0.255 & 0.801 \\
\hline Mean of perceived quality & .098 & 0.341 & 0.036 & 0.286 & 0.776 \\
\hline Mean of loyalty & -0.462 & 0.225 & -0.249 & -2.055 & 0.047 \\
\hline
\end{tabular}




\section{Dependent variable: Mean of RBE}

Above multiple linear regressions show the contribution of each dimension in hakim hyper market. According to the above results the beta of awareness has $84 \%$. While perceive quality have just $3.6 \%$ or $4 \%$. Other dimensions association and loyalty gives the negative result in advance area.

\section{Conclusion and Discussion}

The basic purpose of this study was to investigate the impact of retail brand equity dimensions in backward markets and advance markets. For the purpose we use the survey technique and ask about the preference the customers of both markets. So according to our results and opinions of our respondents.

For this purpose we target 80 customers which 40 were hakim hyper market [backward area] and other were Metro Hyper market [advance area] and percentage of receive back was $80 \%$.

So we conclude that, in backward areas brand loyalty has significant impact on RBE and awareness is just about $1.4 \%$ impact on RBE.

While if we study the advance market then we comes to know that loyalty have least impact while awareness is significant impact [84\%] on market.

\section{References}

[1] The Impact of Brand Personality on Product Sale through Brand Equity [Case Study: Cosmetic Products Retailers]. [2012]. International Journal of Academic Research in Business and Social Sciences, 294-309.

[2] AKHTAR, N., AHMED, I., JAFAR, H. Y., RIZWAN, A., \& NAWAZ., J. M. [2016]. The Impact of Packaging, Price and Brand Awareness on Brand Loyalty: A Reseller Perspective in Mobile Sector of Pakistan. International Review of Management and Business Research, 790-807.

[3] Awan, A. G., \& Rehman, A. U. [2014]. IMPACT OF CUSTOMER SATISFACTION ON BRAND LOYALTY- AN EMPIRICAL ANALYSIS OF HOME APPLIANCES IN PAKISTAN. British journal of Marketing Studies, 18-32.

[4] Baldauf, A., Cravens, K. S., Diamantopoulos, A., \& ZeugnerRoth, K. P. [2009]. The Impact of Product-Country Image and Marketing Efforts onRetailer-Perceived Brand Equity: An Empirical Analysis. Journal of Retailing 85, 437-452.

[5] Bendixen, M., Bukasa, K. A., \& Abratt, R. [2004]. Brand equity in the business-to-business market. Industrial Marketing Management 33, 371- 380.

[6] Brasini, S., \& Tassinari, G. [2003]. THE IMPACT OF BRAND LOAYLTY AND PROMOTIONS ON COUNSUMER BEHAVIOR. Statistica Applicata, 433-453.

[7] Camarero, C., Garrido, M. J., \& Vicente, E. [2010]. Components of art exhibition brand equity for internal and external visitors. Tourism Management 31, 495-504.
[8] del RõÂo, B. A., VaÂzquez, R., \& Iglesias, V. [2001]. The effects of brand associations on consumer response. JOURNAL OF CONSUMER MARKETING, 410-425.

[9] DelVecchio, D., Jarvis, C. B., Klink, R. R., \& Dineen, B. R. [2007]. Leveraging brand equity to attract human capital. Market Lett, 149-164.

[10] Dib, H., \& Alhaddad, A. [2014]. THE HIERARCHICAL RELATIONSHIP BETWEEN BRAND EQUITY DIMENSIONS. European Scientific Journal, 183-194.

[11] Dolatabadi, H. R., Kazemi, A., \& Soltani, N. S. [2012]. The Impact of Brand Personality on Product Sale through Brand Equity [Case Study: Cosmetic Products Retailers]. International Journal of Academic Research in Business and Social Sciences, 294-309.

[12] Gunawardane, N. R. [2015]. Impact of Brand Equity towards Purchasing Desition: A Situation on Mobile Telecommunication Services of Sri Lanka. Journal of Marketing Management, 100-117.

[13] Jara, M., \& Cliquet, G. [2012]. Retail brand equity: Conceptualization and measurement. Journal of Retailing and Consumer Services 19, 140-149.

[14] KARADENIZ, M. [2010]. THE IMPORTANCE OF CUSTOMER BASED STRATEGIC BRAND EQUITY MANAGEMENT FOR ENTERPRISES. Journal of Naval Science and Engineering, 117-132.

[15] Karam, A. A., \& Saydam, S. [2015]. An Analysis Study of Improving Brand Awareness and Its Impact on Consumer Behavior Via Media in North Cyprus [A Case Study of Fast Food Restaurants]. International Journal of Business and Social Science, 66-80.

[16] Khan, N., Rahmani, S. H., Hoe, H. Y., \& Chen, T. B. [2015]. Causal Relationships among Dimensions of Consumer-Based BrandEquity and Purchase Intention: Fashion Industry. International Journal of Business and Management, 172-181.

[17] Kim, H. b., \& Kim, W. G. [2005]. The relationship between brand equity and firms'performancein luxury hotels and chain restaurants. Tourism Management 26, 549-560.

[18] Kim, Y. [2008]. The Impact of Brand Equity and the Company's Reputation on Revenues. Journal of Promotion Management, 89-111.

[19] Martisiute, S., Vilutyte, G., \& Grundey, D. [2010]. Product or Brand? How Interrelationship between Customer Satisfaction and Customer Loyalty Work. European Journal of Interdisciplinary Studies, 5-15.

[20] Musekiwa, A., Chiguvi, D., \& Hogo, H. [2013]. Customer Based Retail Brand Equity [RBE] Dimensions Effect onRetail Brand Equity for OK Supermarket in Bindura. International Journal of Business and Management, 45-54.

[21] Roy, S. S. [2016]. IMPACT OF BRAND EQUITY ON CUSTOMER DELIGHT: A STUDY OF RETAIL SECTOR IN KOLKATA. Asia Pacific Journal of Research, 122-129.

[22] Saleem, A., Ghafar, A., Ibrahim, M., Yousuf, M., \& Ahmed, N. [2015]. Product Perceived Quality and Purchase Intention with Consumer Satisfaction. Global Journal of Management and Business Research: E Marketing, 20-28. 
[23] Sloot, M. L., Verhoef, P. C., \& Franses, P. H. [2005]. The impact of brand equity and the hedonic level of productson consumer stock-out reactions. Journal of Retailing, 15-34.

[24] van Riel, A. C., Mortanges, C. P., \& Streukens, S. [2005]. Marketing antecedents of industrial brand equity:An empirical investigation in specialty chemicals. Industrial Marketing Management 34, 841- 847.

[25] wang, j. [2015]. The relationship between brand association and brand equity in the brand relationship management. International Research Jounral of Arts and Social Science, 1-6.

[26] Wood, L. [2000]. Brands and brand equity: definition and management. Management Decision, 662-669.

[27] Y. L, C. F., \& Lee, G. C. [2011]. CUSTOMER-BASED BRAND EQUITY: A LITERATURE REVIEW. Journal of Arts Science \& Commerce, 33-42.
[28] Yaseen, N., Tahira, M., Anwar, A., \& Gulzar, A. [2011]. Impact of Brand Awareness, Perceived Quality and Customer Loyalty on Brand Profitability and Purchase Intention: A Resellers' View. INTERDISCIPLINARY JOURNAL OF CONTEMPORARY RESEARCH IN BUSINESS, 833-839.

[29] Yee, C. J., San, N. C., \& Khoon, C. H. [2011]. Consumers' Perceived Quality, Perceived Value and Perceived Risk Towards Purchase Decision on Automobile. American Journal of Economics and Business Administration, 47-57.

[30] Yew Leh, F. C., \& Lee, G. C. [2011]. Dimensions of Customer-Based BrandEquity: A Study on Malaysian Brands. Journal of Marketing Research and Case Studies, 1-10.

[31] Zaichkowsky, J. L., Parlee, M., \& Hill, J. [2010]. Managing industrial brand equity: Developing tangible benefits for intangible assets. Industrial Marketing Management 39, 776783. 